\title{
Action cartoons and the effect on children's aggressive behavior
}

\author{
Husnul Khotimah Shobiroh ${ }^{1}$, Muhammad Yusri Bachtiar ${ }^{2}$, Syamsuardi Saodi ${ }^{*}$ \\ 1,2,3 Department of Early Childhood Education, Makassar State University, Indonesia \\ ${ }^{*}$ )corresponding author
}

\begin{tabular}{ccc}
\hline First received: & Revised: & Final Accepted: \\
13 Agustus 2021 & 27 November 2021 & 27 December 2021 \\
\hline
\end{tabular}

\begin{abstract}
Cartoons present a special attraction for children. One program for children that television stations mostly broadcast in action cartoons. They observe characters in action cartoons and repeat what they see or hear. This study aims to determine whether an effect on aggressive behavior in children when watching action cartoons. The research approach used is quantitative. The subject was 12 children aged 5-6 years in the Kindergarten Doa Ibu, Makasar. The researcher used data collection techniques in descriptive statistical analysis and Pearson Product Moment Correlation analysis. The results showed a positive relationship between watching action cartoons and aggressive behavior of children aged 5-6 years and included in the category of moderately influential. To reduce these effects, interventions that must be carried out need to be studied further.
\end{abstract}

Keywords: action cartoons, aggressive behavior, early childhood

\footnotetext{
${ }^{3}$ Corresponding Author:

Department of Early Childhood Education

Universitas Negeri Makassar, Indonesia

Email: syamsuardi@unm.ac.id
} 


\section{INTRODUCTION}

Early childhood is an ideal period to develop various aspects of development. At this time, curiosity and imitation of the environment are very large. Through the theory of Tabularasa in his empiricism flow, John Lucke states that children are born like clean white paper, and it is their environment that will shape a person into an adult human (Surya, 2007). Therefore, the environment becomes one of the supporting factors in shaping the nature or characteristics of children.

Nowadays, so many technological advances sometimes become obstacles in educating children, especially with the increasing number of films specifically for children with various genres that attract the audience. Media effects or influences can be interpreted as differences that occur in a person before and after receiving exposure to messages (information) from the mass media (newspapers, radio, and TV), whether it occurs in the volume of knowledge, new attitudes, or new behaviors (Unde, 2014). For this reason, parents should not allow their children to watch shows that are not appropriate for their age and do not let their children get hung up and end up being addicted to watching television so that they become anti-social.

Television shows, in general, affect the attitudes, views, perceptions, and feelings of the audience so that they are touched, fascinated, or imitating the film's behavior. One of the psychological effects of television is that it seems to hypnotize the audience so that the audience is immersed in the atmosphere of the show (Wulan, 2007). This negative influence makes society increasingly supported by human nature that requires information. Media entertainment is felt to be very important for humans to fulfill their curiosity. Therefore, television is one of the electronic media that is very popular with the general public, especially among children.

The development of television viewing has always been entertainment and increases knowledge. One of the films that can attract children's attention is cartoons. Many cartoons are regularly broadcast every day and present a special attraction for children. There are cartoons that are entertaining, romantic in nature, knowledgeable, and have fight scenes (action). In today's cinema, cartoons are unique and creative, starting from the color design, the roles of the characters, and the atmosphere that attracts children's attention.

A phenomenon, when television dominates children's lives, many parents are worried when they find out that their children are close to television shows. Both close to the show and close to how to watch it. Not only that, many parents are worried about the bad effects of television shows, especially if the programs their children watch are not suitable for their age (Muhtadin, 2011). Examples of scenes that worry parents include cartoons that show scenes of violence or harsh words. They are worried that their children will become lazy to study and their eyes will be damaged due to watching too much television, but they are also afraid that their children will imitate the scenes or words seen on the screen.

The existence of television has a good impact on children's health and has an impact on children's emotional development and children's social life in the future. Media influence can be interpreted as the difference between a person before and after receiving 
exposure to messages (information) from the mass media (newspapers, radio, and TV), whether it occurs in children's knowledge, new attitudes, or new behaviors shown by children.

One program for children that television stations mostly broadcast in action cartoons. Woolfson (Muhtadin, 2011)stated that Japanese-made cartoons are only one type of cartoon that contains $58.4 \%$ of anti-social scenes and $41.6 \%$ of prosocial scenes. Another note explains that cartoons contain anti-social scenes as much as $63.51 \%$. The category of behavior that most often appears in a row is saying rudely as much as $38.56 \%$, harming $28.46 \%$, and ridiculing $11.44 \%$

Social observers view mass communication as a threat to human values and rationality. All media ultimately alienate people from their personal experiences. People may turn to mass media when they are lonely or bored, but once mass media becomes a habit, it can undermine the ability to have meaningful social experiences. Mass media can lead to depersonalization and dehumanization of humans (Unde, 2014).

The number of cartoon shows on television that children favor makes people, especially parents, worried. The parent's concern is caused by the child's ability to think which is still relatively simple. They still tend to assume that what is shown on television is under actual events, and they are still difficult to distinguish which behavior or shows are fictional and which are real stories. It is also still difficult to sort out good behavior according to the nation's values, norms, and personality nation (Bahri, 2017). Scenes of violence, crime, consumerism, including sexual behavior on television screens, are strongly suspected of influencing children's imagination.

Recently, cartoons on television or gadgets in Indonesia tend to increase due to the emergence of cartoon films from abroad, such as in England, the USA, India, Japan, etc. Some of the content in the cartoon contains scenes of violence that children watch. It seems that the freedom practiced by the television medium is judged to be out of control. There is an impression that the media follows people's tastes because they are seen as a market that promises money.

Watching cartoons on a television screen gets more attention than watching them on a gadget screen. It is easier for children to access shows on television than when accessing gadgets that require an internet quota. Violent scenes shown in cartoons on private television make children more curious when applied in real life. In the end, it can lead to new violent behavior or aggressive behavior in children, both among close friends and within their own family.

The spectacular phenomenon of cinema has shaken strongly across the continent to this day. Since the invention of the Lumiere brothers' cinematography technology, many film practitioners have emerged in the entertainment world with their brilliant ideas, factual and fantasy phenomena with energetic spices that bring laughter, emotion, tears, anger, tension, and the like (Devies, 2001).

Several private television stations broadcast cartoons, be it from abroad or from within the country, which greatly influences the development of children's behavior. Children aged 3-7 years have aggressive behavior that is part of their development, one form of 
which is that they often cause problems at home and school. So that it will impact the child's friends or teachers, the main impact of children's aggressive behavior is that children are unable to make friends with other children or play with their friends. The more aggressive behavior he displays, this situation will make the child increasingly unacceptable by his friends.

According to Dayakisni \& Hudaniah (in Syamsuardi, 2014)), aggression, in general, can be interpreted as "attacks by organisms on other organisms, other objects even for themselves". Aggression is good to channel, but it will be channeled through words and thoughts if the behavior is prevented. The social environment also influences the formation of the child's personality, especially the socio-psychological life (Nugroho, 2018). Exposure to violence in the mass media leads to higher levels of aggression, and this finding is supported by several studies that utilize a variety of methodological approaches. Many different mediating processes explain the relationship between media violence and aggressive behavior. Strong media exposure can change what is considered socially acceptable, how the environment is perceived, and how the violence itself is felt (Nugroho, 2018).

Children observe characters on television and repeat what they see or hear; they do not need to perform random behaviors. Hopefully, some of these behaviors will be rewarded (Amelia and Fitriyani, 2016). They can provide one of the earliest experimental evidence that violence shown on television does not stem from aggression; it can lead to more aggressive behavior. The initial observations showed that, on average, the children had disruptive behavior in each class. From the observations made by the author, preschool children at Doa Ibu Kindergarten in Makassar have aggressive behavior including (1) fighting, (2) kicking, (3) hitting, (4) grabbing toys, and (5) throwing things. Research shows that more than $14 \%$ of preschool children exhibit deviant behavior (Purwati and Japar, 2017).

Previous research by Sitinjak (2018) stated the significant influence of cartoon films' choices on children's behavior. Based on the results of research that has been carried out, with the existence of various cartoon films in Indonesia, children begin to get to know something new. What children see continuously will invite their behavior and language in their daily lives and their peers. However, not all children like cartoons and are affected by the action of these cartoons. But most children like cartoons, and this can affect their behavior.

Research by Iswahyuni (2015) is also related to the influence of watching habits on the development of children's behavior. It shows a significant relationship between the influence of watching soap operas and the development of children's behavior in terms of communicating, dressing, and socializing (communication, appearance \& association) is quite adequate with a moderate level of correlation.

Children often show their aggressive behavior to others, either to attract attention or to follow the role of characters in the cartoons they watch. Meanwhile, aggressive behavior usually appears in children: hitting, fighting, mocking, shouting, not wanting to follow orders or requests, crying, and damaging. Children who show this behavior are usually considered a nuisance or troublemaker by the teacher or the community. Based on the 
description above, the researcher was interested in conducting a study entitled "The effect of the intensity of watching action cartoons on the aggressive behavior of early childhood".

\section{METHOD}

The approach used in this research is quantitative. The study was conducted to analyze the effect of watching action cartoons on the aggressive behavior of children aged 5-6 years by emphasizing the analysis of statistical numerical data (numbers). The data that has been collected is then analyzed quantitatively using descriptive statistics so that the formulated hypothesis concludes it is proven or not.

The research approach used is a type of correlation research. Data collection techniques were used in descriptive statistical analysis and Pearson Product Moment Correlation analysis. This type of correlation research is used to determine the level of the habit of watching action cartoon films and the influence of aggressive behavior in early childhood 5-6 years. The population in this study were students in group B in Doa Ibu Kindergarten. The samples used in this study were 12 children in Group B. The samples taken consisted of 4 girls and 8 boys.

The study was conducted in Doa Ibu Kindergarten, Makassar City. Data collection was carried out following the school's teaching and learning process due to the Covid-19 pandemic. The teaching and learning process is carried out at home and or held through online or online media, via Zoom. The activity was in two meetings for screening action cartoons and distributing questionnaires on the habit of watching action cartoons and questionnaires on the development of children's aggressive behavior after watching action cartoons for 1 week. The study was carried out for 1 month by observing children's behavior after watching action cartoons. It is conducted to determine how aggressive the child is after being against friends, family, and people around him. Data were collected from the questionnaire on watching action cartoons and a questionnaire on children's aggressive behavior.

\section{RESULTS}

The technique used is the product-moment correlation technique from Carl Pearson. The results of data analysis with a significant level of 5\% with the help of the Statistical Package Service Solution (SPSS) 22.0 for windows program and obtained the following results:

Table I. Recapitulation of Action Cartoon Watching Habits Indicators

\begin{tabular}{|l|l|c|c|c|}
\hline No. & Category & Interval & Frequency & Percentage \\
\hline 1. & Very high & $95-110$ & - & $0 \%$ \\
\hline 2. & High & $77-94$ & 9 & $75 \%$ \\
\hline 3. & Moderate & $59-76$ & 3 & $25 \%$ \\
\hline 4. & Low & $41-58$ & - & $0 \%$ \\
\hline 5. & Very Low & $22-40$ & - & $0 \%$ \\
\hline \multicolumn{4}{|c}{ Total } & $100 \%$ \\
\hline
\end{tabular}


Based on the results of the data analysis in table I, it is known that 9 respondents are more dominant in the high criteria. It shows the high level of watching action cartoon films for early childhood 5-6 years in the Kindergarten of Doa Ibu. At the same time, the other 3 respondents have a fairly high level of the habit of watching action cartoon films.

Table II. Recapitulation of Child Aggressive Behavior Indicators

\begin{tabular}{|c|l|c|c|c|}
\hline No. & Category & Interval & Frequency & Percentage \\
\hline 1. & Very high & $95-110$ & - & $0 \%$ \\
\hline 2. & High & $77-94$ & 8 & $66,6 \%$ \\
\hline 3. & Moderate & $59-76$ & 4 & $33,3 \%$ \\
\hline 4. & Low & $41-58$ & - & $0 \%$ \\
\hline 5. & Very Low & $22-40$ & - & $0 \%$ \\
\hline \multicolumn{4}{|c|}{ Total } & $100 \%$ \\
\hline
\end{tabular}

The results of the data analysis in table II show that 8 respondents are more dominant in the criteria for high levels of aggressive behavior, while the other 4 respondents have quite high levels of aggressive behavior in early childhood 5-6 years in Doa Ibu kindergarten.

Table III. Hypothesis Testing the Effect of Watching Action Cartoons on Children's Aggressive Behavior

\section{Correlations}

\begin{tabular}{|ll|r|r|}
\hline & & Watching Habits & Aggressive Behavior \\
\hline Watching Habits & Pearson Correlation & 1 &, $806^{* *}$ \\
& Sig. (2-tailed) &, 002 \\
& $\mathrm{~N}$ & 12 & 12 \\
\hline Aggressive Behavior & Pearson Correlation &, $806^{* *}$ & 1 \\
& Sig. (2-tailed) &, 002 & 12 \\
& $\mathrm{~N}$ & 12 & 12 \\
\hline
\end{tabular}

**. Correlation is significant at the 0.01 level (2-tailed).

In table III, the value of $\mathrm{r}$ is 0.806 , which shows a correlation between watching action cartoons and the aggressive behavior of children aged 5-6 years. This figure is categorized as quite influential, which means that there is a $19.4 \%$ effect between watching action cartoon films and aggressive behavior of children aged 5-6 years, of which other variables influence $80.6 \%$. $\mathrm{R}$ table is proportional to or equal to $\mathrm{r}$ arithmetic, indicating that Ha's hypothesis is accepted. And with a significance value (Sig. (1-tailed)) of 0.002, less than the alpha used, which is 0.05 , the hypothesis Ha is accepted. So from the results of these tests, it can be seen that there is a significant and significant correlation between watching action cartoons and the aggressive behavior of children aged 5-6 years in the Doa Ibu Kindergarten. Using the Program Statistical Package Service Solution (SPSS) 22.0 for windows, this test was carried out.

Therefore, there is an effect of showing action cartoon films on the aggressive behavior of children aged 5-6 years in Doa Ibu kindergarten by $19.4 \%$. It can be seen from the results 
of the Product Moment Correlation Coefficient (PMCC) analysis using the Program Statistical Package Service Solution (SPSS) 22.0 for windows. The table shows an r-value of 0.806, which shows the correlation between watching action cartoons and aggressive behavior of children aged 5-6 years, and this figure is categorized as quite influential. With $\mathrm{r}$ table comparable to or equal to $\mathrm{r}$ arithmetic which shows the hypothesis Ha is accepted. And with a significance value (Sig. (1-tailed)) of 0.002, less than the alpha used, which is 0.05 , the hypothesis Ha is accepted.

\section{DISCUSSION}

The test results from these data show a positive and significant effect between watching action cartoon films on the aggressive behavior of children aged 5-6 years in TK Taman PAUD Doa Ibu. In contrast, the rate of contribution by the variable or coefficient of determination is $19.4 \%$. These results show that $19.4 \%$ is influenced by watching Cartoon Action films, and $80.6 \%$ is influenced by various other factors, such as family, the environment around the house or school, parenting patterns, etc

Various cartoon films in Indonesia make children start to know something new. What children see continuously will invite their behavior and language in their daily lives and their peers. However, not all children like cartoons and are affected by the action of these cartoons. But most children like cartoons, and this can affect their behavior. (Sitinjak 2018). According to Rosani (2019), cartoons have a significant influence on the emotional condition of children, so that it affects the attitudes and behavior of children in their environment.

The role of parents is needed to limit and control watching (Wijirahayu et al., 2016) so that children can learn and gain positive knowledge under the child's age because not all cartoons can be enjoyed by children and follow the child's age. Action cartoons shown on television channels or cell phones are nothing less than music and shows containing scenes of violence, fights, and intrigues to harm others. Of course, this will greatly affect children's behavior in the future. It is inseparable from the process of imitation by children of the scenes in action cartoons.

Generally, children's emotional expressions at the age of 5-6 years are fun. The child likes to burst into laughter or flirtatious laughter, squirm, or roll on the floor, and generally exhibits the release of suppressed urges. By adult standards, children's emotional expressions are immature, but this indicates that the child is happy and well adjusted in children. For this reason, parental supervision is needed when children are watching movies, be it cartoons, especially action cartoons (Soetjiningsih, 2012).

Suppose in early childhood the role of parents and caregivers is very dominant in children's socio-emotional development, then in late childhood. In that case, they are influenced by the home, community, and school environment. Various studies have shown that barriers in social-emotional development result in the emergence of problems in everyday life. Waltz (Mashar, 2011) mentions that several emotional, social skills support children's school reading lines not to behave aggressively: confidence, curiosity, intentionality, self-control, relatedness, capacity to communicate, and cooperativeness. 
On the other hand, cartoons also positively impact if children are scheduled and accompanied when watching television. If the cartoons they watch contain elements that are not good, the children will be aggressive and will always imitate the actions contained in the cartoons, in addition to the impact of negative behavior. However, there are also positive impacts for children, such as increasing children's creativity, growing children's social values, being easy to speak Indonesian, etc. It depends on the assistance of parents to children.

In the view of behaviorists, human behavior arises from the stimulus received by the organism in question, both from external stimuli and normal stimuli. However, most organisms behave in response to external stimuli. Cognitive psychologists view individual behavior as a stimulus-response, but there is the ability to determine the behavior taken from within the individual (Julianto, 2004). In this case, the individual can determine his behavior in an active state. Likewise, children's behavior is an act or action and word of a person whose nature can be observed, described, and exemplified by every child and anyone who directly or indirectly observes it.

\section{CONCLUSION}

Based on the research conducted regarding the effect of watching action cartoons on aggressive behavior in early childhood, 5-6 years, watching action cartoons shown on television is influenced by various factors. Action cartoon films have attracted children's attention to continue watching these shows, which are packaged in such a way with interesting things so that they will linger in front of the television to watch action cartoon films. The use of excessive time watching cartoons certainly affects children's behavior patterns in everyday life, so it is necessary to control watching hours by parents considering the behavior shown in cartoons looks cool and easy for children to imitate

\section{REFERENCES}

Amelia, R., Fitriyani, R., 2016. Hubungan Intensitas Menonton Tayangan Kekerasan Di Televisi Dengan Perilaku Agresiv Yang Dilakukan Anak Usia Sekolah Di Madrasah Diniyah Awaliyah Nurul Huda Pajar Bulan. Psikis: Jurnal Psikologi Islami, 2(2), 197.

Arikunto, S., 2002. Prosedur Penelitian Suatu Pendekatan Praktik. Rineka Cipta, Jakarta.

Bahri, K., 2017. Dampak Film Kartun Terhadap Tingkah Laku Anak. Banda Aceh.

Devies, E., 2001. Buku Saku: Penemuan. Erlangga, Jakarta.

Edi, P., 2008. Animation Movie. Informatika, Bandung.

Effendy, O.U., 2000. Ilmu Komunikasi, Teori dan Praktek. Rosdakarya, Remaja Bandung.

Fatimah, E., 2006. Psikologi Perkembangan. Pustaka Setia, Bandung.

Hamdi, A.S., Baharuddin, 2014. Metode Penelitian Kuantitatif Aplikasi Dalam Pendidikan, 1st ed. Deepublish, Yogyakarta. 
Iswahyuni, E. 2015. Pengaruh Kebiasaan Menonton Sinetron terhadap perkembangan Perilaku Anak Usia Sekolah di SDN Pao-Pao Kecamatan Somba Opu Kabupaten Gowa. UIN Alauddin Makassar.

Izzaty, R.E., 2008. Perkembangan Peserta Didik. UNY Press, Yogyakarta.

Julianto, 2004. Psikologi Dakwah. Banda Aceh: Ar-Raniry.

Mashar, R., 2011. Emosi Anak Usia Dini Dan Strategi Pengembangannya, 4th ed. Prenadamedia Group, Jakarta.

Muhtadin, 2011. Pengaruh Film Kartun Sinchan Dan Doraemon Pada Perilaku Anak. Jkt. Univ. Prof Dr Moestopo.

Musi, M.A., Sadaruddin, Mulyadi, 2007. Kontribusi Bermain Peran untuk Mengembangkan Sosial-Emosional Anak Usia Dini. Golden Age: Jurnal Pendidikan Anak Usia Dini, 1(2).

Nando, Pandjaitan, N.K., 2012. Hubungan Antara Perilaku Menonton Film Kekerasan Dengan Perilaku Agresi Remaja. Jurnal Sosiologi Pedesaan, 6(1), 18-35.

Noor, J., 2017. Metodologi Penelitian, Kencana. ed. Jakarta.

Nugroho, G.E., 2018. Tayangan Televisi dan Agresivitas Anak. Surakarta.

Nurmalitasari, F., 2015. Perkembangan Sosial Emosi pada Anak Usia Prasekolah. Buletin Psikologi, 23(2), 103-111.

Purwati, Japar, M., 2017. Orangtua Pendidikan, Kepribadian, dan Perilaku Mengganggu mereka Anak. Internasional Journal of Instruction, 10(3). https://doi.org/10.12973/iji.2017.10315a

Rompas, F.Y., 2005. Dampak Siaran Televisi Terhadap Perilaku Agresif Anak. Jkt. J. INSANI, No. 8 Th XXII.

Rosani, 2019. Pengaruh Film Animasi Shiva Terhadap Imitasi Perilaku Anak Di Kelurahan Tonyamang Kecamatan Patampanua Kabupaten Pinrang. Parepare Fak. Ushuluddin Adab Dan Dakwah Institus Agama Islam Negeri IAIN.

Sitinjak, S.R., 2018. Pengaruh Pilihan Film Kartun Terhadap Perilaku Anak-Anak Di Pekon Luas Kecamatan Batu Ketulis Kabupaten Lampung Barat. Jurnal Kultur Demokrasi, $5 / 8$.

Soetjiningsih, C.H., 2012. Perkembangan Anak: Sejak Pembuahan Sampai dengan KanakKanak Akhir. Seri Psikologi Perkembangan, Prenada Media.

Sugiyono, 2016. Metode Penelitian Kuantitatif, Kualitatif, R\&D. Bandung, Alfabeta.

Suliyanto, 2011. Ekonometrika Terapan - Teori dan Aplikasi dengan SPSS. Yogyakarta, CV Andi Offset.

Sukanta, W., Ahmad, S., Asiyah, S., 2017. Pengaruh Media Pembelajaran Film Kartun Terhadap Hasil Belajar Ips Terpadu (Geografi) Pada Materi Lingkungan Hidup Dan Pelestariannya. Jurnal Swarnabhumi, 2(1), 23-29. 
Surya, H., 2007. Percaya Diri itu Penting. PT Elex Media Komputindo, Jakarta.

Syamsuardi, 2014. Proceeding Early Childhood Education for Future Asia: Issues and Challanges. Semarang State Univ.

Unde, A.A., 2014. Televisi dan Masyarakat Pluralistik. Prenadamedia Group, Jakarta.

Wijirahayu, A., Krisnatuti, D., Muflikhati, I., 2016. Kelekatan Ibu-Anak, Pertumbuhan Anak, Dan Perkembangan Sosial Emosi Anak Usia Prasekolah. Bogor Inst. Jurnal Ilmu Keluarga \& Konsumen, 9(3), 171-182.

Wulan, B.S., 2007. Pengaruh Menonton Film Kartun Yang Mengandung Unsur Kekerasan Terhadap Perilaku Agresif Pada Anak Siswa Kelas IV SDN Kereo 1 Tangerang. 